\title{
The Origine of the Private Property in Albania and Its Restitution to the Legitimate Owners
}

\author{
Mimoza Mehilli \\ Candidate doctorate the European University of Tirana, Email: mehilli.mimoza@gmail.com
}

Doi:10.5901/ajis.2015.v4n3p175

\begin{abstract}
The restitution of the private property to the legitimate owner is still continuing even after so many years of system change and is a non treated problem for the Albanian society. There is a wide spread of this problem as long as there are no steps to resolve it according to the law "For the constitution and comnensation of the property to the legitimate owners". The property has been a non realized right for Albanian people for over 50 years of the communism period, especilly for the inheritance owners who not only did not have their properties at that time, but still do not have it yet. It is very difficult to resolve this problem with the Albanian state, and it has been a source of violence to the various so called owners. This problem is a challenge for the economic development and country integration. Many countries have had the same problem as Albania, but with the changes of the law for the private property this problem is resolved, but not in Albania; even though the changes of the law have been happening for the last 25 years, without bringing the results expected from the legitimate owners. This study will describe this problem in our country, how it has been resovled until now and the measures that the Albanian state has taken to give back the private property this compared to the other countries of the region in order to make it clearer why this problem has lasted for so long.
\end{abstract}

Keywords: private property, economic development, political transition, legitimate owner

\section{Introduction}

The destruction of the comunism regime in 1990 in Albania did not bring the long time expected rights of the legitimate owners to get their inherited properties form their families. The private property, which is a main rights of human beings, in Albania has been not respected for 50 years and it has been denied in the most cruel way. The owners were striped from every right and were not given any other means of living. Their property was given to the people in the villages that did not have any land, and later by giving it back to the state. The Albanian state for many years has been one of the biggest owners of the land, which would be envied from the richest kings of the world. One of the questions that comes up when we study this problem of our country is the origine of all this property, where di dit come from and how was it inherited from one generation to the other. It is understandable that the origine is very old, begining since 1020 but not in the consolidated form and goes on nowdays.

At the begining and during the World War II many indivuduals and groups such as religious sects, hebrews, rome, political enemies etc. were deprived fromn the right of their properties as a result of the national social politics (natzis). Most of these properties after the war were restituted to their legitimate owners according to the law of the allied invasion or as the specific countries laws. But this did not happen in the countries where the comunism regime won, as on the other side of Europe. The property abduction continued more fiercely in cruel ways driven by other goals derived from the comunism doctrine.

This property abduction continued up to the destruction of the communism regime and the property was given to the legitimate owner, in most of the ex communism countries. This process ended really fast, differing from Albania, where this process is still continuing.

Countries like Bulgary in 1992, Germany in 1994, Rumania, Croacia and Poland in 1996, Macedonia in 1998, Bosnje and Herzegovina in 2000, Montenegro in 2002 finished this process on timely matters. Two left behind countries in this process in Europe are Albania and Serbia. Serbia, considering the process of documentation and the preparation time of the restitution, is much better than Albania. In our country, the communism regime took everything from the owners and divided the properties as a "gift from the party". The private property was totally destroyed and there were no laws that protected the rights of the owners. During the war period, after the formation of the comunism party, the land was given to the albanian villagers with slogans like the land belongs to "the ones who work it" ... 
After the war, the first step of the communism government was the expropriation of the ex owners who were persecuted and followed in all forms and methods. The distribution of the land to the villagers with the agricultural reform in 1945 and later in 1946 was a miserable way of the private land abduction, and also the begining of the country destruction. The cooperative collections later on was a way that the comunism state became a gread feudal owner, as after this process there was absolutely no more private property in the country.

In the begining of 1990 the comunsim fell and everybody thought that the long time suffering of the ex-owners was comming to an end, but in fact this did not happen. The real owners are still waiting for their properties even after 25 years. The law „For the restitution and compensation of the private property " did not do anything for the restitution of the land, it remained a dream as none of the parties in the government did not have any interest in giving back the land to the legitimate owners. A massive abuse was conducted with the law 7501 „For the land" which ruined further more the rights of the legitimate owners.

\section{The Goal and the Objectives of the Study}

The aim of the study is to analyze the origine of the private property in Albania and to argue the rights of the legitimate owners for the restitution of their property; to give recommendations how to regulate the actual law in the European Human Court, which decisions are bringing a big damage in our country, in order to end all the problems that exist for the compensation of the private property.

The main objective of this study is to present a clear view of the private property in Albania and its place before and after 25 years of democracy, comparing the other ex-communism countries and presenting the problems of non implementation of the Convention of Civil Human Rights, which is ratified form Albania and is above the Albanian laws.

\section{The Questions of the Study and the Methodology}

The research questions clarified in this study will be:

1- What is the origine of the private property in Albania ?

2- Why do the ex-owners have the right to have their property returned?

3- What is the role of the property restitution to the legitimate owner on the albanian economy?

This is a descriptive and analyzing study, but we also will use the comparison to the other countries with similar problems.

\section{Describing, Analyzing and Interpreting the Data}

\subsection{The origine of the private property in Albania}

The origine of the private property in Albania is thought to have its beginning around $10^{\text {th }}$ century, where for the first time we find the acts of land donation of the Byzantine Emperor for the Albanian bishops one in 1018 and the other in 1020.

Later on, during XI-XIV centuries the village population together with their lands, were connected to the religious or non religious individuals with the reason to pay taxes to these people, but not to the state of Albania (up to the begining of the XI century). This fact shows that in the albanina villages the relation to the land had started to change. During the XI century the typical form of the property was the institute of the property ${ }^{1}$ which was widely used in the Albanian villages. The ownership of the property was not free, but conditioned by the property partner who got all the material benefits that came from this economy, but on the other hand the partner had to obey the Emperor, by being summned for the military service. As a conditioned gift, these properties could not be donated, sold or inherited to the heir of the land partners. This type of condition started to fade around XIII-XIV centuries and the land partners started to have more rights and privileges. At the end of the $14^{\text {th }}$ century the property started to exhibit the features of independent feudals. During this time there were three types of properties:

1- The property --- a conditioned property with military service

2- Bashtine-unconditioned property with ownership title from the presentators of the aristocracy, land worked by

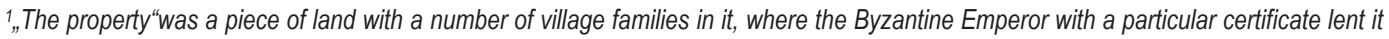
to laik or religious individuals with a conditioned ownership. 
the villgers

3- Small Bashtins --- unconditioned property exploited and worked by the owner himself

The transition to the feudal system gave the property an unconditioned status. With the invasion of Albania from the Otoman Empire there were many changes that happened to the private property. At this time, especially in the beginning of the $18^{\text {th }}$ century and $19^{\text {th }}$ century the feuds started to have the rights not only to administer their property, but also to expend it being protected by the high Turkish Power. During this time we notice three types of land ownership:

A) The feudal property ownd by the feuds

B) The property owned by the Turkish state

C) The property owned by the religious sects

During this time the ottoman impact and its laws were sanctioned in all Albanian territory, in most parts of Albania people obeyed the Albanian customary rights of the property.

\subsubsection{The Customary Right of property}

The origine of the customary norms in all Albania, including South and North belong to the ancient times, before the roman invasion, since the illyrian times (IV- I century B.C). according to Shtjefen Gjeçov this right is related to the name of the king Pirro of the Epire state. These norms were orally forwarded during the centuries up to the first half of the XX century, always being in the oral form but not written anywhere, which is the main feature of the customary right. The ancestors always considered the private property as the power to possess their real estate properties, which in various times appeared in different forms.

The illyrians and arber ancestors preserved and transmitted the Code of the Customary Right without any changes to the rights for their lands, by implementing only this right at any time without obeying the laws presented by the invaders. The Kanuns are the living testimony that the south and north communities did not live in anarchy and arbitrarity, but applied these norms for the regulation of the social relations between people in different areas of life.

In the analyses of the albanian customary right especially of the kanun of Lek Dukagjin, we will notice that not only the collective property was known but also the private property was protected too, as a untouchable property, even giving penalties when the private property was violated. The Kanuns which are the most important part of the customary rights recognize the property in three forms:

1- The church property

2- The collective property

3- The private property

This division from different times of kanuns, is seen in all of them. For their importance and the importance of the property at these times, we will analyze the articles of the High Council of Justice when the only law was the Kanun.

In the division of the Lek Dukagjin Kanun ${ }^{2}$, we notice that the first place in the beginning of it is the property of the church and article 2 determined that:

1. The church is the owner of all the assets, the land and houses, in and out the church area.

2. The church owns parts of the mountains, under the water, and in the mills of the area.

According to the High Council of Justice the collective property in the article 215 determines : "All the families partly own the collective property administered from the village".

The definition of the collective property is found in the article 217, part 12 where is stated: " the valley, the mountain and the fields are collective, as for the woods, land and everything else ». In this article it is clear that all the community had the rights to use the collective property such as the pastures, where everybody was able to send the animals there, to cut woods in the mauntains for their families, to use the streams in the village etc.

Other then the church property and the collective property, an important place had the private property also. The High Council of Justice in the article 12 starts with the private property and exactly with its assigment. The forth book is " The house, the thing and the property" and we can say that it is a totally private right, regulated with the disposition on the private property in a perfect and detailed way, how it is obtained and inherited. The violation of the private property is only found in the last century, but the violation of someones house in the Albanian Customary Right is determined since the 15th century where it is stated that: "you can not visit someone in their house without warning". The article 213 states that every living house should have its property. Through this article the High Council of Justice recognizes the right of

2 Gjecovi Shtjefen, “Kanun of Lek Dukagjinit”ALBIN Shkoder 1933 
every home to have its property, which served to feed the family. This recognition of the property from the law (Kanun, High Council of Justice and the Kanun of Laberia) shows the importance that the private property has, the property of a house, what is included in it, how is it obtained and its protection.

By analyzing the High Council of Justice and the Kanun of Laberia, we see not oanly the similarities to the private property, but in the same time we see that these Kanuns were the only applied law in the Southern and Northern part of Albania.

\subsubsection{The property up to 1990}

Although the country gained a new status after the declaration of Independence on 28-11-1912, all the governments that came one after the other did not disappear the right of landowners to property or private property itself but rather sanctioned and recognized it. It is proved by the Civil Code of the Kingdom of Albania of the year 1929. This recognition and protection of private property would be valid up to the end of 1944 when the Communist government that came after the war did not recognize the private property but only the state property.

The agricultural reform of 1945 and 1946 clearly showed that the brutal robbery of the property and distribution to poor farmers and the ones who had no land, would bring consequences to the abolition of private ownership of land. Although it was greatly said that this reform did not give peasants the ownership titlea for the land (as the cadastral records of that time do not present these distributions of land), but they were given the land to use and the communist government would take it back through collectivization up to ignoring the private property in the Constitution of 1976, which recognizes only state property. This condition lasted till the destruction of the communism regime.

\subsubsection{The property after 1990 to today}

With the change of system emerged the first problems private property. Former owners who had waited for years to get back their rights, finally thought it was time for their problem to be resolved. Meanwhile in all of Eastern Europe, where communism had dominated, started the wind of change and they began to implement the laws on restitution and compensation of properties, but in Albania the government continued to steal the property by still making the legitimate owner suffer again.

In 1991 the Albanian Parliament of the time approved the law 7501 "On Land" dated 19.07.1991, a law which is in complete contradiction with human rights to private property. This law, which brought the greatest stalemate in restitution, distributes the agricultural land, not to the legitimate owner but to the peasants who worked on farms and agricultural cooperatives, even though they never had private property. The way of adoption and the contents of this law show that it is inconsistent with the Constitution of Albania (1998) and with Section 41 of the Constitution which states that:

1- "The right of private property is guaranteed.

2- The property is won by donation, inheritance, bying and any other clasical method forseen in the Civil Code.

3- The law can forsee expropriations, or limitation in excercising the right of the property only for public interests.

4- Expropriations, or limitation in excercising the right of the property, are only allowed versus a justified compensation.

The land granting under the Law 7501 is contrary to the ways of acquiring property mentioned above under the Constitution of Albania, therefore, we can say that this law is unconstitutional.

The law "On the restitution and compensation of former owners" no. 7698 dated 15.04 .1993 in Article 1 states: "The law recognizes former owners or their heirs the right of ownership for the nationalized properties, expropriated or confiscated under the laws, regulations and court rulings issued after November 29,1944 , or taken unjustly by the state by any means and defines the ways and measures for the return and compensation".

Under this law, the Albanian state needed to restore the former owners the denied property over the years, but this did not happen, on one hand the dispute between the two laws and on the other the Albanian governments themselves that were not interested in a final settlement of this problems. Today after 25 years of these discussions, this problem is still unresolved. Constant changes in Albanian legislation, have added more problems in the area of the right of ownership. Although private property in our country is a denied heritage, it will remain there unchanged.

The problem of property restitution is not only a social problem but also an economic one, since the damages awarded by the European Court of Human Rights costs millions of euros to our country economy.

By November 2014, the Court of Strasbourg has introduced 79 new lawsuit requests, 13 of which are won by the legitimate owners. Within the month of February 2015, sources from Strasbourg court declared that this court will start 
judging 43 other issues on Albanian property. The Strasbourg Court has required two solutions from the Albanian government:

1. To urgently implement the announced decisions of the Court and to start the financial and physical compensation for the altered properties

2. To free the occupied lands and return to owners the free properties, before the new Strasbourg decisions which, according to a estimation range in average a value of 27 million euros.

According to the registry of the Court, until the end of 2014, this court has had in judging process 439 files on Albanian properties, of which $35 \%$ are for violation of individual rights, $42 \%$ were for violation of property rights and $23 \%$ for property occupation according to the Albanian law.

Everything we mentioned above show the difficulties that the restitution of the private property still faces. This fact and the penalties that the Albanian government continues to take for the violation of property rights would weigh more on the state budget which would hamper further more the property restitution and compensation, as well as the Albanian economy.

\section{Conclussions/ Recommendations}

By analyzing the legal framework issued in 25 years of democracy by the Albanian Parliament we can say that despite the work done by the institutions responsible for the issues of property, problems with private property, with the return of property to the rightful owner, there have been and continue to be a major problem for the country's social and economic development. Even though the Albania's new government, which is paying for the damages of previous governments, has requested a deadline postponement of the compensations to the issues resolved by the Court of Strasbourg, this is not a solution.

The large number of issues that continue to go to this court shows that it is required a much greater attention and serious reforms in the process of property rights. It is the duty of Parliament and the Albanian Government to review the laws on restitution and compensation of the property, facilitation of procedures and timely resolution of unresolved problems of ownership.

The Agency for Property Restitution and Compensation should consider in a shorter time and resolve the issues that are found in its offices for years. The physical property would be the best solution of this problem, as the monetary compensation will aggravate further more the Albanian economy.

\section{References}

Albanian Constitution of 1998

The law number 7501 of the year 1991 for the land

The law Nr. 7698 of 15 April , 1993, "For the restitution and compensation of the private property to the former owners"

The law nr. 9235, date 29.07.2004 "For the restitution and compensation of the private property"

2012 The law Nr.55/2012 "Some changes and addings in the law Nr: 9235, date 29.7.2004 "For the restitution and compensation of the private property, changed".

Gjecovi Shtjefen, "The Canun of Lek Dukagjini"ALBIN Shkodra 1933

Albania Progress Report", European Commission Staff Working Report, October 2012

The intersectiorial strategy, the reform in the area of property rights 2012 - 2020", The justice Ministry, Albanian Republic, June 2012

The jurisprudence of the Europian Court of Human Rights : A review of the selected rulings for the restitution and compensation of the property February 2011

The source: World Bank report , The Center of Public Reports

TV Clan newpaper 28 August 2013 - 15:25 https://sq.wikipedia.org/mobile.ikub.al/.../

The relations of the property in the albanian villages https://sq.wikipedia.org/..The feudal property in Albania 
